\title{
Physicochemical and Bioactive Compounds in Carrot and Beetroot Juice
}

Simran Arora ${ }^{1}$, Saleem Siddiqui ${ }^{2}$, Rakesh Gehlot ${ }^{2}$

10.18805/ajdfr.DR-1363

\begin{abstract}
Carrot and beetroot are mostly used for salad and juice purposes. To know the physicochemical and bioactive composition of the locally grown carrot and beetroot, the present investigation was carried out. A physicochemical and bioactive compound like total soluble solids, total sugars, reducing sugars, titrable acidity, $\mathrm{pH}$, ascorbic acid, total antioxidant activity, anthocyanins, betanin, total phenols and total carotenoids were determined from fresh carrot and beetroot juices. The results showed that fresh red carrot juice contained a high amount of $\beta$-carotenoids $(4.59 \mathrm{mg} / 100 \mathrm{~mL}$ ) content. Freshly extracted beetroot juice contained $62.20 \%$ DPPH scavenging antioxidant activity, $990.7 \mathrm{mg} / 100 \mathrm{~mL}$ total phenols, $790 \mathrm{mg} / \mathrm{l}$ anthocyanins, $520.3 \mathrm{mg} / \mathrm{l}$ betanins. The results suggest that carrot and beetroot juices are a rich source of nutrients and bioactive compounds thus can be used for value addition in food formulations.

Keywords: Beetroot juice, Bioactive compounds, Carrot juice, Nutritional quality.

Asian Journal Of Dairy and Food Research (2019)
\end{abstract}

\section{INTRODUCTION}

C arrot (Daucus carota L.) is one of the most important seasonal root vegetables of Apiaceae (Umbelliferae) family grown throughout the world. It is an inexpensive and highly nutritious vegetable. China is the largest producing country of carrot in the world (FAO, 2011). In India, the carrot is produced 10.93 lakh tones annually from an area of 68,000 ha during 2014-15. Haryana is the leading producer of carrot with 2.51 lakh tonnes in an area of 18000 ha, followed by Tamil Nadu, Punjab, Karnataka and Uttar Pradesh (NHB, 2016)

Carrot is an excellent source of $\beta$-carotene, a precursor of vitamin $A$, which neutralizes the effect of free radicals (Yoon et al., 2005). It is rich in antioxidants like a-carotene, $\beta$-carotene, flavonoids and phenolic derivates, which have anticarcinogenic activities, reduce inflammatory insult, and modulate immune response (Zhang and Hamauzuet, 2004; Dias, 2012). It also contains small amounts of other lipophilic antioxidants like lutein and lycopene having importance in eye health and protection from age-related macular degeneration (Tanumihardjo and Yang, 2005).

Beetroot (Beta vulgaris) is botanically classified as an herbaceous biennial from the Chenopodiaceae family and has several varieties with bulb colors ranging from yellow to red. Deep red-colored beetroots are the most popular for human consumption, both cooked and raw as salad or juice. Beetroot contains $87.4,1.35,0.3,1.9,2.56$ and $1.4 \%$ of moisture, protein, fat, dietary fiber, total fiber, and mineral contents respectively. It is also rich in valuable active compounds such as glycine betaine, saponins, pigments (vulgaxanthin I, vulgaxanthin II, indicaxanthin, betanin, prebetanin, isobetanin, and neobetanin) and pool of phenolic compounds that includes phenolic acids, flavonoids, and organic and inorganic acids (Kujala et al., 2000; Singh and Hathan, 2014). Thus, the objective of this study was to carry out the physicochemical $\overline{~ I C A R-C e n t r a l ~ I n s t i t u t e ~ o f ~ P o s t-H a r v e s t ~ E n g i n e e r i n g ~ a n d ~ T e c h-~}$ nology, Ludhiana, Punjab, India 141004

${ }^{2}$ Centre of Food Science and Technology, CCSHAU, Hisar, India 125004

Corresponding Author: Rakesh Gehlot, Centre of Food Science and Technology, CCSHAU, Hisar, 125 004, Email: arorasimran245@ gmail.com

How to cite this article: Arora, S., Siddiqui, S. and Gehlot, R. (2019). Physicochemical and bioactive compounds in carrot and beetroot juice. Asian Journal Of Dairy and Food Research, 38(3): 252-256.

Source of support: Nil.

Conflict of interest: None

Submitted:16-04-2018 Accepted:26-09-2019 Published: 30-10-2019

and bioactive characterization of carrot and beetroot juice so that we can supplement it with other fruit juices and products

\section{Materials and methods}

The experiment was conducted at the Centre of Food Science and Technology, CCSHAU Hisar in the year 2016. Raw materials (red carrot and purple beetroot) were procured from local orchards/market, Hisar. Before juice extraction, carrot and beetroot were washed thoroughly under running tap water and peeled to remove adhered soil particles and small roots attached to their skin. Then the juice was extracted separately by centrifugal juice extractor. The procedure adopted for juice extraction is presented in Figure 1.

\section{Analysis of physicochemical parameters}

The following chemical parameters were analyzed for fresh carrot and beetroot juice: total soluble solids, total sugars, reducing sugars, titrable acidity, $\mathrm{pH}$, ascorbic acid, total antioxidant activity, total phenols, and total carotenoids. However, anthocyanins and betanin content 


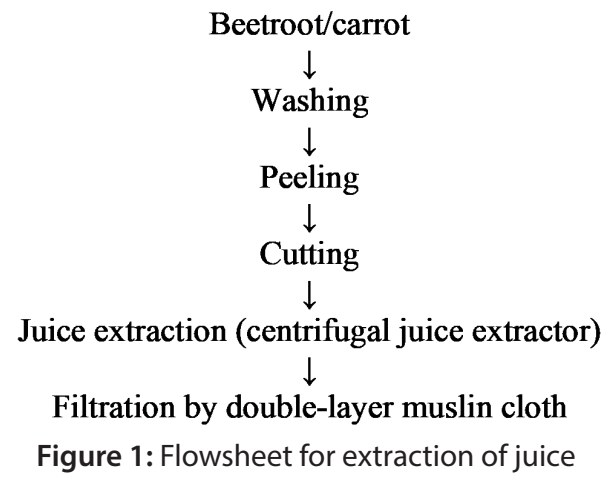

were determined only in beetroot because these pigments are not present in red carrot.

\section{Total soluble solids}

Total soluble solids (TSS) of fresh juice were estimated at ambient temperature using a hand refractometer (Erma, Japan) having a range of $0-32 \%$.

\section{Total and reducing sugars}

Total and reducing sugar of fruit juices was estimated by the titration method, as suggested by Hulme and Narain (1931). The results were calculated and expressed in $\mathrm{g}$ of sugar per $100 \mathrm{~g}$.

\section{Titrable acidity}

Total acids were extracted in water and were determined using the titration method described by A.O.A.C. (2005). Total acids were extracted and titrated against $0.1 \mathrm{~N} \mathrm{NaOH}$ using a few drops of phenolphthalein as an indicator.

\section{$\mathrm{pH}$}

The $\mathrm{pH}$ of fresh juice was determined by a $\mathrm{pH} 700$ digital meter at $25 \pm 2^{\circ} \mathrm{C}$. Before estimation, $\mathrm{pH}$ meter was calibrated using a pH buffer solution of $\mathrm{pH} 4.0,7.0$, and 10.2.

\section{Ascorbic acid}

The ascorbic acid content was determined using a 2-6 Dichlorophenol-indophenol (dye) visual titration method (Ranganna, 2014).

\section{Antioxidant activity}

The percentage of 2, 2-diphenyl-1-picrylhydrazyl (DPPH) radical scavenging activities of fruit juices was determined by the slight modification of the spectrophotometric method, as suggested by Shimada et al., (1992). DPPH dye was prepared by dissolving methanol, and the mixture stands in the dark at refrigerated temperature for 12 hour. Then, the DPPH working solution was diluted with methanol to an absorbance of between $0.3-0.6$ at $519 \mathrm{~nm}$. After that, an aliquot of $100 \mu \mathrm{L}$ tested samples was added to $3 \mathrm{~mL}$ of DPPH working solution and measured at thirty minutes of reaction at $517 \mathrm{~nm}$. Lower absorbance of the reaction mixture indicated higher free radical scavenging activity/ antioxidant activity.

\section{Anthocyanin}

Anthocyanin content of beetroot juice was determined by $\mathrm{pH}$ difference method as per the procedure of Askar and Treptow (1993). The sample was mixed with $20 \mathrm{~mL}$ of pH 1.0 buffer, centrifuge, and filtered to remove haze or sediments. The dilution factor was determined by diluting the test portion with $\mathrm{pH} 1.0$ buffer until the absorbance at $520 \mathrm{~nm}$ is within the linear range of spectrophotometer (0.4 to 0.6$)$. Using this dilution factor, prepared dilution for the same sample with a $\mathrm{pH} 4.5$ buffer. The absorbance of the test portion diluted with $\mathrm{pH} 1.0$ buffer and $\mathrm{pH} 4.5$ buffer were recorded at both 520 and $700 \mathrm{~nm}$. The anthocyanin content was calculated and expressed as cyaniding-3-glucoside.

\section{Betanin or betacyanin}

The betanin content of beetroot juice was assayed by modification of the differential spectrophotometry method suggested by Nilsson (1970). The sample was mixed with 20 $\mathrm{mL}$ of phosphate buffer $\mathrm{pH} 6.5$, centrifuge, and filtered to remove haze or sediments. The absorbance was taken at 538 and $700 \mathrm{~nm}$. The purpose of measuring absorbance at 700 $\mathrm{nm}$ is to correct the haze or turbidity and subtracting it from the absorbance at the wavelength of maximum absorption $(538 \mathrm{~nm})$.

\section{Total phenols}

Total phenols were determined using a method suggested by Amorium et al. (1997). Phenols from juice were extracted with 80 percent acetone, and results were calculated using the standard curve expressed in terms of tannins as $\mathrm{mg} / 100 \mathrm{~mL}$.

\section{Total carotenoids}

Total carotenoids of carrot juice were determined spectrophotometrically by a slight modification of the method described by Rodriguez-Amaya (2004). The sample was extracted with chilled acetone, centrifuged, and the supernatant was transferred to the separating funnel. Petroleum ether was added to this solution and mixed thoroughly. After 5 min, two layers were separated on standing. Discarded the lower layer and the absorbance of the above layer was read at $452 \mathrm{~nm}$ against petroleum ether as blank.

\section{Results ANd discussion}

\section{Carrot juice}

It was observed that fresh carrot juice contained $8.33 \%$ total soluble solids, $5.23 \mathrm{~g} / 100 \mathrm{~g}$ total sugars, and $2.79 \mathrm{~g} / 100 \mathrm{~g}$ 
reducing sugars (Table 1). The results are in agreement with the previous findings of Moza (2010) who reported that fresh carrot juice had $7.4 \%$ of total soluble solids, $4.67 \%$ of total sugars and $2.16 \%$ of reducing sugars. Similarly, Jothi et al. (2014) found that carrot juice contained $4.91 \%$ of total sugars and $2.15 \%$ of reducing sugars. The mean values of titrable acidity and $\mathrm{pH}$ were found to be $0.06 \%, 6.15$, respectively which are in accordance with the findings of Zadernowski et al. (2010) who reported $0.19 \mathrm{~g} / 100 \mathrm{~g}$ acidity in fresh red carrot. Similarly, Jothi et al. (2014) recorded pH (5.00) and titrable acidity $(0.05 \%)$ in carrot juice.

Ascorbic acid is a water-soluble vitamin. It acts as an important nutrient because of its antioxidant, anti-

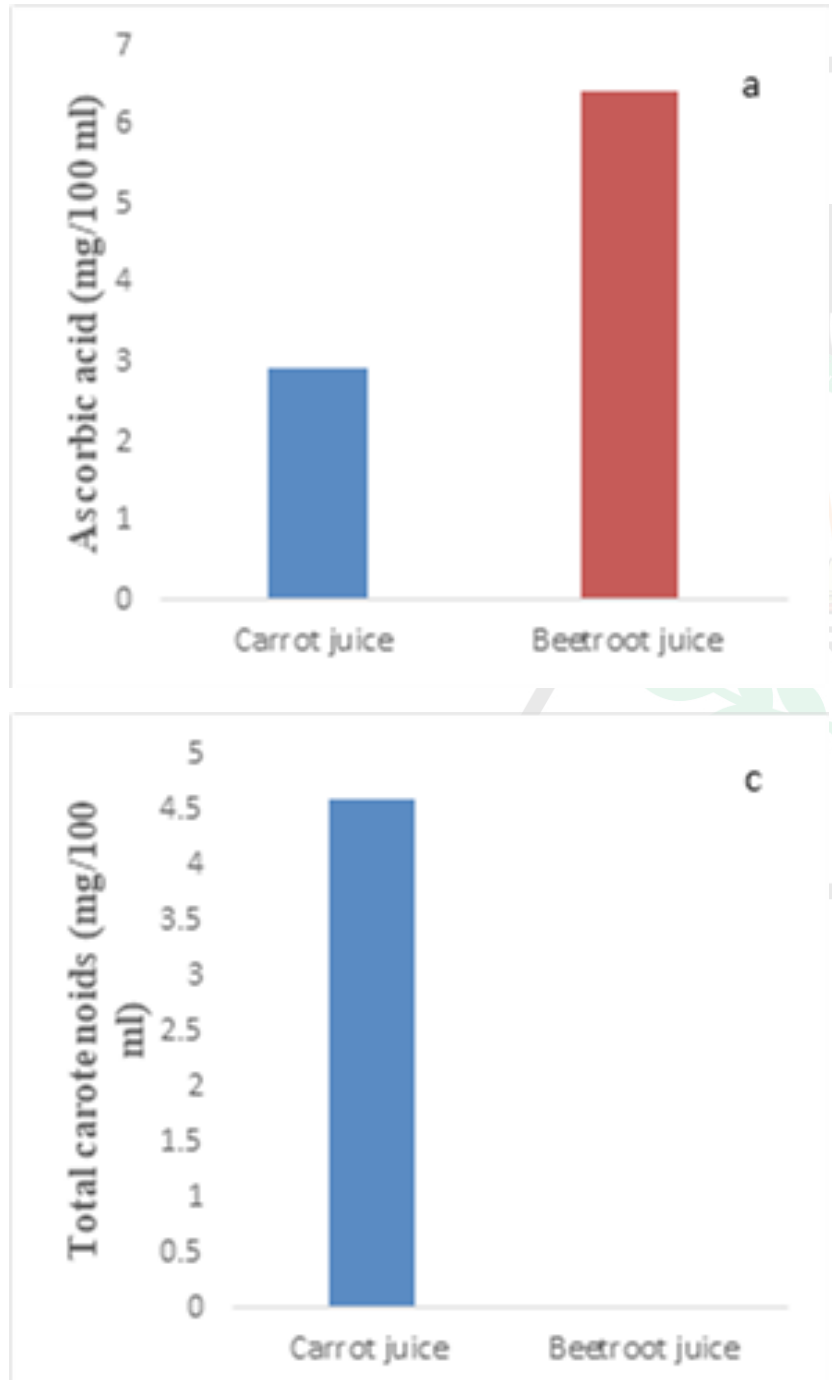

atherogenic, and immune modulator effects. The data in Figure $2 \mathrm{a}$ and $2 \mathrm{~b}$ shows mean value of $2.94 \mathrm{mg} / 100 \mathrm{~mL}$ of ascorbic acid and $189.2 \mathrm{mg} / 100 \mathrm{~mL}$ of total phenols which are in agreement with the previous findings Leahu et al. (2013) who reported that fresh red carrot juice had $5.54 \mathrm{mg} / 100 \mathrm{~g}$ of ascorbic acid and $352 \mathrm{mg} / 100 \mathrm{~mL}$ of total phenols. Similarly, Bystricka et al. (2015) observed total phenols in the range of 8.12 to $11.37 \mathrm{mg} / 100 \mathrm{gm}$ in five varieties of carrot.

The carotenoids are natural pigments that give both appearance and attractiveness to beverages as well as add nutritional value due to antioxidant property. The results in Figures $2 \mathrm{c}$ and $2 \mathrm{~d}$ show the antioxidant activity of $32.31 \%$ scavenging of DPPH and total carotenoids of $4.59 \mathrm{mg} / 100$

Figure 2: Bioactive compounds in carrot and beetroot juice.

Table 1. Chemical analysis of carrot and beetroot juices

\begin{tabular}{llllll}
\hline Parameters & TSS (\%) & $\begin{array}{l}\text { Total sugars } \\
(\mathrm{g} / 100 \mathrm{~g})\end{array}$ & $\begin{array}{l}\text { Reducing sugars } \\
(\mathrm{g} / 100 \mathrm{~g})\end{array}$ & $\begin{array}{l}\text { Titrable acidity } \\
(\mathrm{g} / 100 \mathrm{~g})\end{array}$ & $\mathrm{pH}$ \\
\hline Carrot juice & $8.33 \pm 0.58$ & $5.23 \pm 0.16$ & $2.79 \pm 0.07$ & $0.06 \pm 0.03$ & $6.15 \pm 0.06$ \\
Beetroot juice & $10.00 \pm 0.00$ & $6.67 \pm 0.57$ & $2.39 \pm 0.21$ & $0.05 \pm 0.02$ & $8.03 \pm 0.11$ \\
\hline
\end{tabular}

Values are mean \pm Standard Error (SE) 
$\mathrm{g}$ which are in agreement with the findings of Moza (2010) who observed the antioxidant activity of $31.8 \%$ and total carotenoids of $8.85 \mathrm{mg} / 100 \mathrm{~mL}$ in carrot juice. The observed differences in our study may be due to a different variety and environment. Similarly, Bystricka et al. (2015) observed antioxidant activity in the range of $6.88 \%$ to $9.835 \%$, and $\beta$-carotenes in the range of $24.58-124.28 \mathrm{mg} / 100 \mathrm{~kg}$ in five varieties of carrot.

\section{Beetroot juice}

It was observed that fresh beetroot juice contained $10.00 \%$ total soluble solids, $6.67 \mathrm{~g} / 100 \mathrm{~g}$ total sugars, and $2.39 \mathrm{~g} / 100$ g reducing sugars (Table1). The results are in conformity with the findings of Khade (2015) who studied the physicochemical composition of beetroot juice and reported that beetroot had TSS content of was $10^{\circ} \mathrm{Brix}$, total and reducing sugars of 4.20 and $7.93 \%$. Similarly, Kazimierczak et al. (2016) analyzed total and reducing sugars in juices in relation to the production system and processing technology for beetroot and found that it contained total sugars $(1.73-7.85 \mathrm{~g} / 100 \mathrm{~g})$ and reducing sugars $(1.21-7.31 \mathrm{~g} / 100 \mathrm{~g})$. The mean values of titrable acidity and $\mathrm{pH}$ of beetroot juice was found to be $0.05 \%$ and 8.03 respectively, which are in accordance with the findings of Perez and Perez (2009) reported that beetroot juice contained titrable acidity (5.61 mg/100 mL) and pH (6.34). Similarly, Dambalkar et al. (2016) recorded acidity $0.06 \%$ and pH 8.2 in beetroot juice.

Fruits and vegetable juices contain a higher amount of antioxidants, which reduces the incidences of cancer, heart diseases, and boosts the immune system. The data in Figures $2 \mathrm{a}$ and $2 \mathrm{~d}$ shows ascorbic acid $(6.44 \mathrm{mg} / 100 \mathrm{~g})$ and antioxidant activity (62.20\% scavenging of DPPH) of beetroot juice which is in agreement with the findings of Dambalkar et al. (2016) who found that beetroot juice contained 10.07 $\mathrm{mg} / 100 \mathrm{~g}$ of ascorbic acid on a fresh weight basis. Wruss et al. (2015) observed antioxidant capacity in the range of 19.7 to $37.9 \mathrm{mM}$ TE in seven varieties of beetroot grown in upper Austria. Similarly, Vasconcellos et al. (2016) found that beetroot juice contained $80.48 \%$ of total antioxidant activity.

Phenolic content in fruits and vegetables prevents and treats many oxidative stress-related diseases. In the present study (Figure 2b), the total phenolic content of beetroot juice was found to be $990.7 \mathrm{mg} / 100 \mathrm{~mL}$ which is higher than carrot juice. The results of the present study are in agreement with the previous findings of Venkatachalam et al.,(2014) who reported a total phenolic of $57.64 \mathrm{mg} / 100 \mathrm{~g}$ for fresh beetroot. Anthocyanins are water-soluble pigments and members of the flavonoid group of phytochemicals. These compounds play an important role in the color of many fruits, vegetables, and products derived from them. The data in Figure $2 f$ represents anthocyanins content $(790 \mathrm{mg} / \mathrm{l})$ of beetroot juice which is in accordance with the previous findings of Manea (2013) who analyzed bioactive compounds in beetroot juice during preservation by refrigeration and found that fresh beetroot juice contained $0.54 \mathrm{~g} / \mathrm{L}$ anthocyanins content.
Kovarovic et al. (2017) reported varied content of anthocyanin $(14.48$ to $84.50 \mathrm{mg} / \mathrm{kg})$ in five varieties of beetroot.

The betanin is an important pigment, possesses the antioxidant ability, and provides protection against free radicals. The data in Figure 2 e shows that beetroot juice had $520.3 \mathrm{mg} / \mathrm{L}$ betanins. The result was in agreement with the previous findings of Wruss et al. (2015), who reported that betacyanin content ranged from $465-807 \mathrm{mg} / \mathrm{l}$ in different varieties of beetroot grown in upper Austria. Similarly, Czapski et al. (2009) found red pigment (betacyanins) in the juice, which ranged from $570-1630 \mathrm{mg} / \mathrm{L}$ in 11 different cultivars of beetroot.

\section{Conclusion}

It can be concluded that carrot and beetroot juice contained a high amount of valuable bioactive compounds that prevent degenerative processes (free radical formation) in the human body system. As these vegetable juices have nutritional and medicinal properties, would need to be supplemented with other fruit juices and products in the diet to meet up with the body requirements for healthy nutrition.

\section{Acknowledgments}

The authors acknowledge CFST-CCSHAU, Hisar for providing all other facilities to accomplish this work.

\section{References}

A.O.A.C. (2005). Official Methods of Analysis. Association of Official Analytical Chemists. Washington, D.C. $16^{\text {th }}$ edition.

Amorium, H.V., Dougall, D.K., and Sharp, W.R. (1997). The effect of carbohydrate and nitrogen concentrations of phenol synthesis in plant scarlet rose cells grown in tissue culture. Physiologia Plantarum, 39: 91-95.

Askar, A., and Treptow, H. (1993). Ascorbic acid. In: Quality assurance in tropical fruit processing. Springer Laboratory, New York, pp. 28-29.

Bystricka, J., Kavalcova, P., Musilova, J., Vollmannova, A., Tomas, T.O.T.H., and Lenkova, M. (2015). Carrot (Daucus carota L. ssp. sativus (Hoffm.) Arcang.) as a source of antioxidants. Actaagriculturae Slovenica, 105(2): 303-311.

Clifford, T., Constantinou, C.M., Keane, K.M., West, D.J., Howatson, G., and Stevenson, E.J. (2017). The plasma bioavailability of nitrate and betanin from Beta vulgaris in humans. European Journal of Nutrition, 56(3): 1245-1254.

Czapski, J., Mikołajczyk, K., and Kaczmarek, M. (2009). Relationship between the antioxidant capacity of red beet juice and contents of its betalain pigments. Polish Journal of food and nutrition sciences, 59(2)

Dambalkar, V.S., Rudrawar, B.D, and Poojari, V.R. (2016). Study of Physico-chemical properties and sensory attributes of beetroot-orange RTS drink. International Journal of Science and Research, 4(10), 589-594.

Dias, J.S., (2012). Major Classes of Phyto-nutraceuticals in vegetables and health benefits: A Review. Journal of Nutritional Therapeutics, 1, 31-62. 
FAO. (2011). Food and Agriculture Organization of the United Nations. Statistics web site http://www.fao.org

Hulme, A.C, and Narain, R. (1931). The ferricyanide method for the determination of reducing sugars. A modification of Hagedom-Jensen-Hanes technique. Biochemistry Journal, 25(4), 1051-1061.

Jothi, J.S., Karmoker, P., and Sarower, K. (2014). Quality assessment of mixed fruit squash: Physico-chemical analysis, sensory evaluation, and storage studies. Journal of the Bangladesh Agricultural University, 12(1), 195-201.

Kazimierczak, R., Silakiewicz, A., Hallmann, E., Srednicka-Tober, D., and Rembialkowska, E. (2016). Chemical composition of selected beetroot juices in relation to beetroot production system and processing technology. Notulae Botanicae Horti Agrobotanici Cluj-Napoca, 44(2), 491-498.

Khade, A.A. (2015). Studies on preparation and storage of ready to serve beverages from beetroot juice. Ph.D. Thesis submitted to MPKV, Rahauri, India.

Kovarovic, J., Bystricka, J., Tomas, J., and Lenkova, M. (2017). The influence of variety on the content of bioactive compounds in beetroot (Beta vulgaris L.). Potravinarstvo Slovak Journal of Food Sciences, 11(1), 106-112.

Kujala, T.S., Loponen, J.M., Klika, K.D., and Pihlaja, K. (2000). Phenolics and betacyanins in red beetroot (Beta vulgaris) root: Distribution and effect of cold storage on the content of total phenolics and three individual compounds. Journal of Agricultural Food Chemistry, 48, 5338-5342.

Leahu, A., Damian, C., Carpiuc, N., Oroian, M., and Avramiuc, M. (2013). Change in color and physicochemical quality of carrot juice mixed with other fruits. Journal of Agroalimentary Processes and Technologies, 19, 241-246.

Manea, I. (2013). Evolution of bioactive compounds in fruit juices during preservation by refrigeration. Revue Roumaine de Chimie, 58(7-8), 619-622.

Moza, J. (2010). Effect of pulsed electric field on extraction and quality of carrot juice. M.Sc. A thesis submitted to CCSHAU, Hisar.

National Horticulture Board. (2016). Horticultural statistics at a glance.Oxford University Press, New Delhi, p 199.

Nilsson, T. (1970). Studies into the pigments in beetroot (Beta vulgaris L. ssp. vulgaris var. rubra L.) .Lantbrukshogskolans Annaler, 36, 179-219.

Perez, E., and Perez, L. (2009). Effect of the addition of cassava flour and beetroot juice on the quality of fettuccine. African Journal of Food Science, 3(11), 352-360.

Ranganna, S. (2014). Handbook of analysis and quality control for fruit and vegetable products. Tata McGraw Hills Publishing Co. Ltd., New Delhi.

Rodriguez-Amayaa, D.B. (2004). A guide to carotenoids analysis in foods. ILSI Press, Washington. Pp 35-36.

Shimada, K., Fujikawa, K., Yahara, K., and Nakamura, T. (1992). Antioxidative properties of xanthan on the antioxidation of soybean oil in cyclodextrin emulsion. Journal of Agricultural and Food Chemistry, 40, 945-948.

Singh, B., and Hathan, B. S. (2014). Chemical composition, functional properties, and processing of Beetroot-a review. International Journal of Science and Engineering Research, 5(1), 679-684.

Tanumihardjo, S.A., and Yang, Z. (2005). Carotenoids: Epidemiology of health effects. In: Encyclopedia of human nutrition. 2nd ed. Caballero B, Allen L, Prentice A, editors. Oxford: Elsevier Ltd. pp 339-45.

Vasconcellos, J., Conte-Junior, C., Silva, D., Pierucci, A. P., Paschoalin, V., and Alvares, T.S. (2016). Comparison of total antioxidant potential, and total phenolic, nitrate, sugar, and organic acid contents in beetroot juice, chips, powder, and cooked beetroot. Food Science and Biotechnology, 25(1), 79-84.

Venkatachalam, K., Rangasamy, R., and Krishnan, V. (2014). Total antioxidant activity and radical scavenging capacity of selected fruits and vegetables from South India. International Food Research Journal, 21(3), 1039-1043.

Wruss, J., Waldenberger, G., Huemer, S., Uygun, P., Lanzerstorfer, P., Muller, U., Hoglinger, O., and Weghuber, J. (2015). Compositional characteristics of commercial beetroot products and beetroot juice prepared from seven beetroot varieties grown in Upper Austria. Journal of Food Composition and Analysis, 42, 46-55.

Yoon, K.Y., Cha, M., Shin, S.R., and Kim, K. S. (2005). Enzymatic production of a soluble-fiber hydrolyzate from carrot pomace and its sugar composition. Food Chemistry, 92, 151-157.

Zadernowski, R., Piłat, B., Czaplicki, S., \& Ogrodowska, D. (2010). Characteristics of the black carrot (Daucus carota ssp. sativus var. Atrorubens Alef). Publisher UWM, 438.

Zhang, D., and Hamauzu, Y. (2004) Phenolic Compounds and Their Antioxidant Properties in Different Tissues of Carrots (Daucus carotaL.).Journal of Food, Agriculture, and Environment (JFAE), 2, 95-100. 